\title{
Terminal Bacteroid Differentiation Is Associated With Variable Morphological Changes in Legume Species Belonging to the Inverted Repeat-Lacking Clade
}

\author{
Jesús Montiel, ${ }^{1}$ Attila Szúcs, ${ }^{1}$ Iulian Z. Boboescu, ${ }^{1,2}$ Vasile D. Gherman, ${ }^{2}$ Éva Kondorosi, ${ }^{1}$ and \\ Attila Kereszt ${ }^{1}$ \\ ${ }^{1}$ Institute of Biochemistry, Biological Research Center of the Hungarian Academy of Sciences, Temesvári krt. 62,6726 Szeged, \\ Hungary; ${ }^{2}$ Research Institute for Renewable Energy, Polytechnic University of Timisoara. Piaţa Victoriei Nr. 2, 300006 \\ Timisoara, Romania
}

Submitted 20 September 2015. Accepted 3 December 2015.

\begin{abstract}
Medicago and closely related legume species from the inverted repeat-lacking clade (IRLC) impose terminal differentiation onto their bacterial endosymbionts, manifested in genome endoreduplication, cell enlargement, and loss of cell-division capacity. Nodule-specific cysteine-rich (NCR) secreted host peptides are plant effectors of this process. As bacteroids in other IRLC legumes, such as Cicer arietinum and Glycyrrhiza lepidota, were reported not to display features of terminal differentiation, we investigated the fate of bacteroids in species from these genera as well as in four other species representing distinct genera of the phylogenetic tree for this clade. Bacteroids in all tested legumes proved to be larger in size and DNA content than cultured cells; however, the degree of cell elongation was rather variable in the different species. In addition, the reproductive ability of the bacteroids isolated from these legumes was remarkably reduced. In all IRLC species with available sequence data, the existence of $N C R$ genes was found. These results indicate that IRLC legumes provoke terminal differentiation of their endosymbionts with different morphotypes, probably with the help of NCR peptides.
\end{abstract}

The Fabaceae family, comprising over 18,000 species, is the third largest family of flowering plants that constitutes approximately $27 \%$ of the world's crop production (Vance et al. 2000). The foundation of their economic and ecologic importance is their ability to establish a mutualistic association with $\alpha$ - and $\beta$-proteobacteria, commonly known as rhizobia (Graham and Vance 2003). This symbiotic relationship provides reduced nitrogen to the host while the microsymbiont receives carbon sources in exchange, as well as a niche to multiply. The mutualistic association develops in the rhizosphere where, after a species-specific molecular dialogue, the bacteria attach to the root hairs and, eventually, are internalized through a tubular structure called an infection thread (Ferguson et al. 2010). Simultaneously, a nodule primordium is formed by reactivation of the cell division in the cortex. Subsequently, the infection thread reaches the nodule primordium and enters into the nodule cells, in which the

Corresponding author: A. Kereszt; E-mail: kereszt.attila@brc.mta.hu

*The $e$-Xtra logo stands for "electronic extra" and indicates that two supplementary figures and one supplementary table are published online.

(C) 2016 The American Phytopathological Society bacteria are released into the plant cells as organelle-like structures called symbiosomes in which the bacteria are encapsulated in membranes of plant origin. Within the symbiosomes, the rhizobia differentiate into nitrogen-fixing bacteroids catalyzing the conversion of atmospheric nitrogen into ammonia (Popp and Ott 2011).

In legumes, three different bacteroid morphotypes have been described (Bonaldi et al. 2011; Mergaert et al. 2006; Vasse et al. 1990): the E morphotype corresponds to elongated bacteroids that can be also branched, the $\mathrm{S}$ morphotype represents enlarged spherical bacteroids, while the U morphotype bacteroids have unmodified size and rod-shape morphology similar to their free-living siblings. The DNA content of the $\mathrm{E}$ and $\mathrm{S}$ morphotype bacteroids is amplified and associated with cell enlargement, while the genome content of the U-type bacteroids is $1 \mathrm{C} / 2 \mathrm{C}$, just as that of the free-living cultured rhizobia (Mergaert et al. 2006). In addition, E (and S) morphotype bacteroids lose their cell-division ability and their irreversible differentiation is terminal. In contrast, the U morphotype bacteroids isolated from nodules are able to form colonies. Studies on Rhizobium strains that can nodulate legumes from different clades revealed that the fate of bacteroids is controlled by the host plant (Bonaldi et al. 2011; Mergaert et al. 2006; Sen and Weaver 1981). In Medicago truncatula of the inverted repeatlacking clade (IRLC), which form E-type bacteroids, nodulespecific cysteine-rich (NCR) peptides were shown to be plant factors controlling terminal bacteroid differentiation (Van de Velde et al. 2010). Members of the NCR gene family has been identified in some IRLC legumes, such as Vicia faba, Medicago sativa, Trifolium repens, Galega orientalis, Pisum sativum, and Astragalus sinicus, while the NCR genes were absent in the genome of those legumes (Lotus japonicus, Glycine max, Glycine sojae, Phaseolus vulgaris, Cajanus cajan) in which the bacteroids were U type (Chou et al. 2006; Crockard et al. 2002; Frühling et al. 2000; Jiménez-Zurdo et al. 2000; Kaijalainen et al. 2002; Kato et al. 2002; Mergaert et al. 2003). In M. truncatula, this gene family consists of more than 600 members, which are exclusively expressed in nodules (Alunni et al. 2007; Guefrachi et al. 2014; Mergaert et al. 2003; Young et al. 2011).

Since morphological differentiation of bacteroids is not taking place in all legumes, it is not required, per se, for the maintenance of the endosymbiotic bacterial population, prompting the question why certain legumes impose this differentiation process on their rhizobium partners. While this question remains entirely open at present, two published studies provide strong argument for a selective advantage to 
the plant imposing terminal bacteroid differentiation on the partner. Phylogenetic analysis and ancestral state reconstruction suggested that the ancestral morphotype of bacteroids was the undifferentiated $\mathrm{U}$ morphotype and that the differentiated $\mathrm{E}$ and $\mathrm{S}$ morphotypes appeared several times independently in the legume family (Oono et al. 2010). Moreover, the same researchers observed a higher symbiotic performance of the E or S morphotype bacteroids compared with U morphotype bacteroids (Oono and Denison 2010). However, even if these studies are attractive arguments, the molecular and physiological bases for the selective advantage to the plant remain unknown.

Terminally differentiated bacteroids have been observed in Medicago, Pisum, Vicia, Trifolium, and Galega species (Mergaert et al. 2003); however, the lack of bacteroid enlargement was reported in two IRLC legumes, Cicer arietinum and Glycyrrhiza lepidota (Lee and Copeland 1994; Oono et al. 2010). In the IRLC phylogeny (Fig. 1), Cicer species are placed into a branch within the Vicioid subclade that is between the branches containing Galega and Medicago (and Ononis, Trifolium, Pisum, Vicia) species, while Glycyrrhiza species form the most basal subclade; thus, the two genera are in nonsister phylogenetic groups. These reports suggested that bacteroids with terminal differentiation are absent in these members of the IRLC and prompted us to closely explore the morphotype of bacteroids in a number of genera that represent different branches of the IRLC phylogenetic tree (Wojciechowski et al.
2004). Though to different extents, increased bacterial cell size and DNA content as well as low reproductive capacity of the isolated bacterial population were observed in nodules of all lineages that accompanied the formation of bacteroids with E- and even S-like morphotypes. Moreover, in all species in which nodule transcriptome or genomic sequences are available, the presence or the expression of $N C R(-$ like) genes was observed. These observations suggest that imposing terminal bacteroid differentiation on the symbiotic partner is a general feature in the IRLC legumes, probably via the action of symbiotic peptides. The data collected in this study provides a wider overview of bacteroid differentiation in the IRLC to further understand the emergence of this process during evolution in the species belonging to this clade.

\section{RESULTS}

Variable morphotypes of bacteroids in the IRLC nodules.

To investigate the fate of bacteroids in plants belonging to different genera of IRLC (Wojciechowski et al. 2004) (Fig. 1), Glycyrrhiza uralensis, Onobrychis viciifolia, Astragalus canadensis, Galega orientalis, Cicer arietinum, and Ononis spinosa plants were inoculated with Mesorhizobium tianshanense (University of Helsinki, Faculty of Agriculture and Forestry, Division of Microbiology and Biotechnology [HAMBI] 3372), Rhizobium sp. (HAMBI 2045), Mesorhizobium sangaii (HAMBI 3318), Rhizobium galegae bv. orientalis (HAMBI 540), Mesorhizobium ciceri,

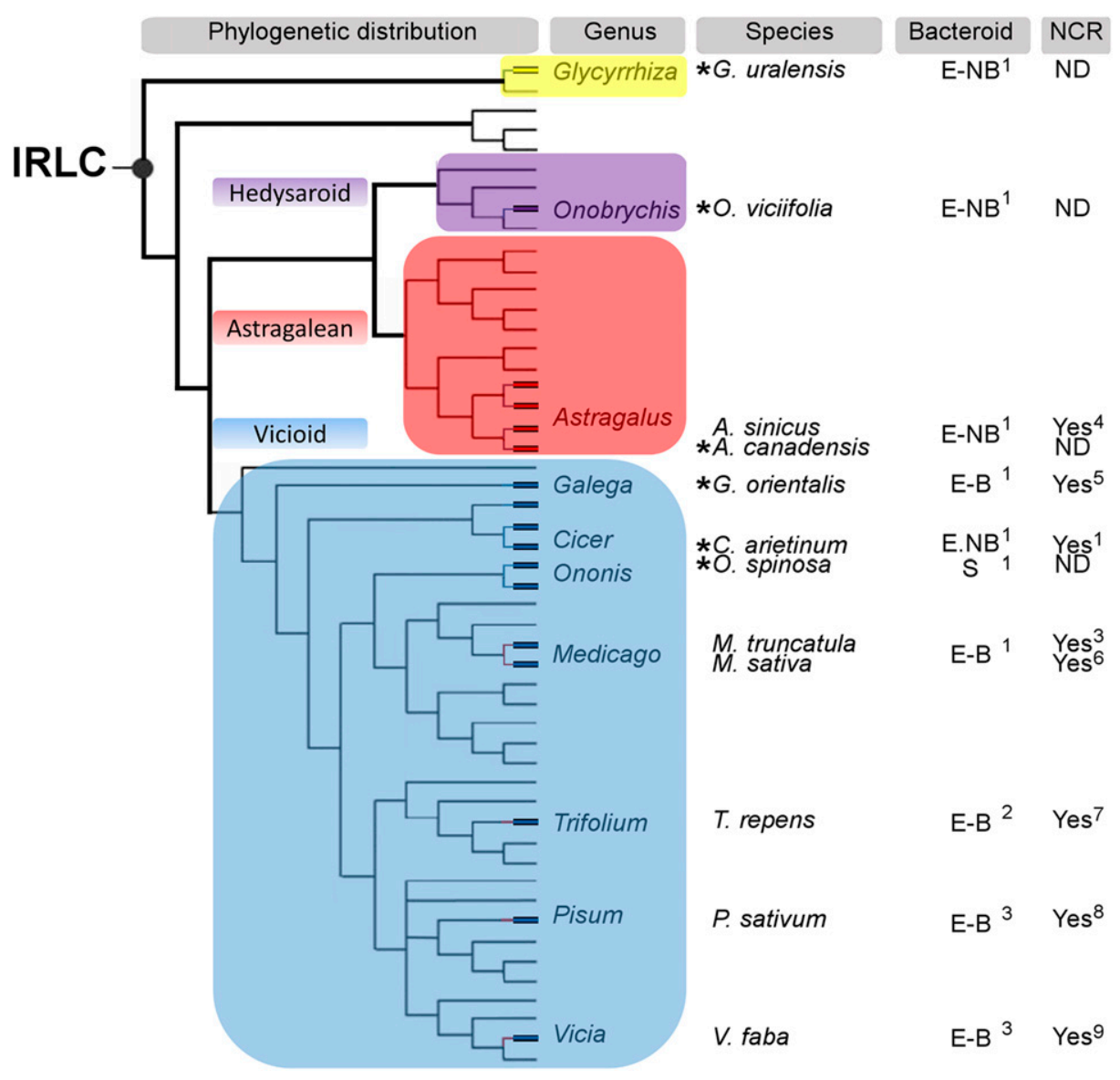

Fig. 1. Phylogenetic relationships and the presence of nodule-specific cysteine-rich peptide (NCR) genes in the inverted repeat-lacking clade (IRLC) legumes. The image was modified from Wojciechowski et al. (2004) to highlight the species studied in this work (asterisks), the morphotype of the bacteroids and whether the expression of NCR genes has been detected in their nodules. Major clades within IRLC are shaded with different colors in the tree. Sources are indicated by superscript numbers as follows: ${ }^{1}=$ this work, ${ }^{2}=$ Bergersen $(1955),{ }^{3}=$ Mergaert et al. $(2006),{ }^{4}=$ Chou et al. $(2006),{ }^{5}=$ Kaijalainen et al. $(2002)$, ${ }^{6}=$ Jiménez-Zurdo et al. (2000), ${ }^{7}=$ Crockard et al. (2002), ${ }^{8}=$ Kato et al. (2002), and ${ }^{9}=$ Frühling et al. $(2000)$. E-NB = elongated not-branched, EB = elongated branched, $\mathrm{S}=$ spherical, and $\mathrm{ND}=$ not determined. 
and Rhizobium sp. (HAMBI 2029), respectively. Full names of the legumes analyzed in this study are used in order to avoid confusion that might be caused by the abbreviations. Fully mature nodules were collected at 4 weeks postinoculation (wpi), to analyze their structure and the bacteroids. Longitudinal sections of the nodules showed that all species formed indeterminate nodules that were properly infected by their rhizobial partners (Supplementary Fig. S1). Interestingly, comparison of free-living bacteria
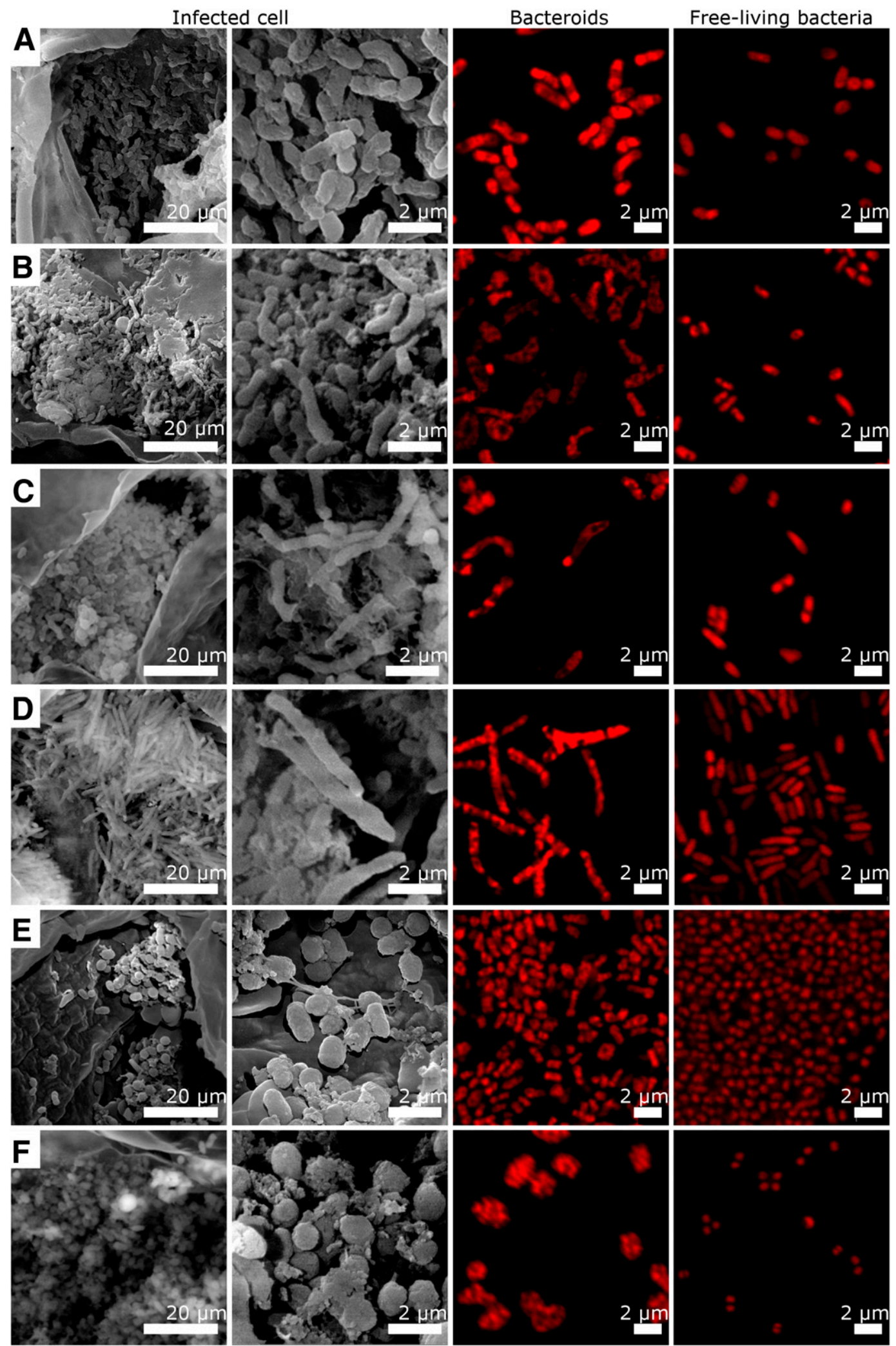

Fig. 2. Bacteroid morphology in the nodules of inverted repeat-lacking clade legumes. Bacteroids in infected nodule cells (first and second columns) and isolated, propidium iodide (PI)-stained bacteroids (third column) from A, Glycyrrhiza uralensis, B, Onobrychis viciifolia, C, Astragalus canadensis, D, Galega orientalis, E, Cicer arietinum, and F, Ononis spinosa were investigated with scanning electron (first and second columns) and confocal microscopies (third column) and were compared with PI-stained free-living bacteria (fourth column). 
and isolated bacteroids by confocal microscopy and the inspection of infected nodule cells by scanning electron microscopy (SEM) revealed drastic differences in the bacteroids' morphotypes (Fig. 2). Galega orientalis hosted long, Y-shaped bacteroids similar to those found in Medicago truncatula. In Astragalus canadensis and Onobrychis viciifolia, bacteroids were elongated, while in Cicer arietinum and Glycyrrhiza uralensis, bacteroids were less enlarged and looked like the U morphotype cells. Moreover, no branched cells were observed in these four species. The morphotype of the bacteroids from Ononis spinosa nodules is noteworthy, since the bacteroids resemble the $\mathrm{S}$ morphotype cells that have been observed in nodules formed on Arachis and Aeschynomene species
A

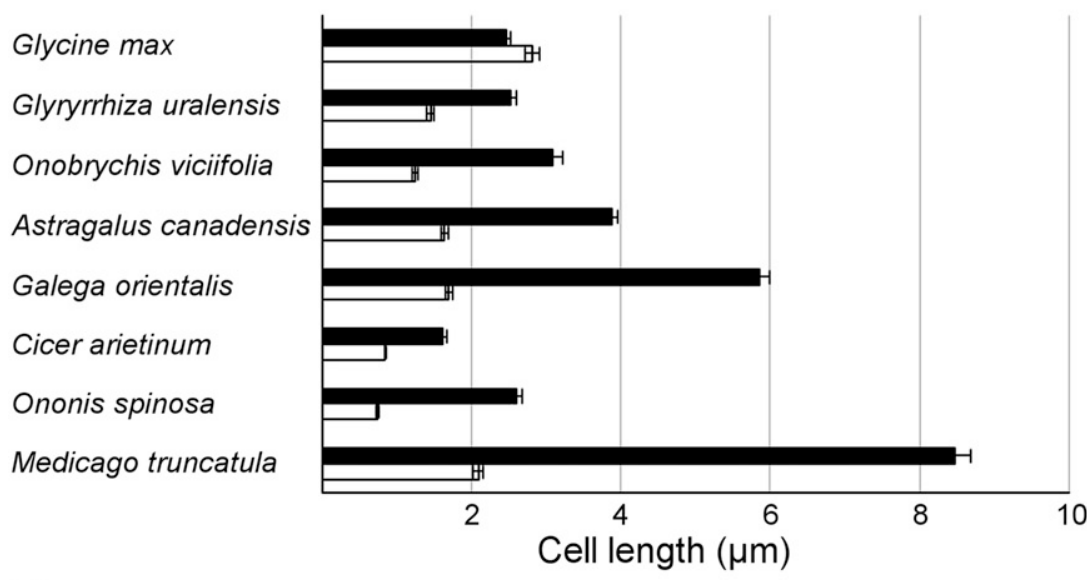

B

Glycine max

Glyryrrhiza uralensis

Onobrychis viciifolia

Astragalus canadensis

Galega orientalis

Cicer arietinum

Ononis spinosa

Medicago truncatula

C

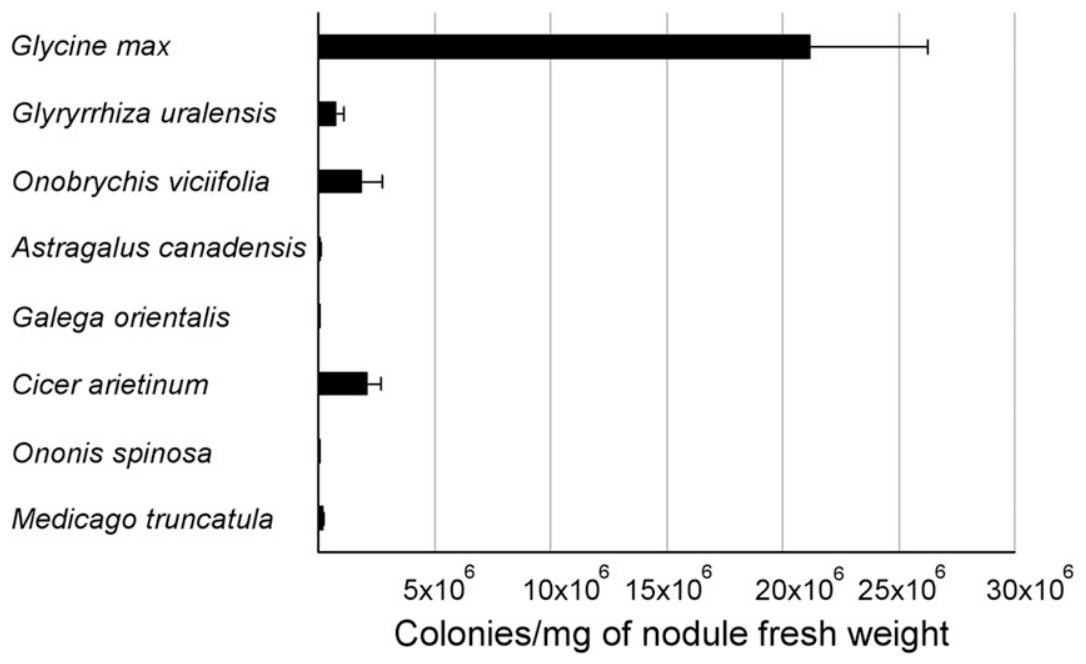

- Bacteroids $\square$ Free-living

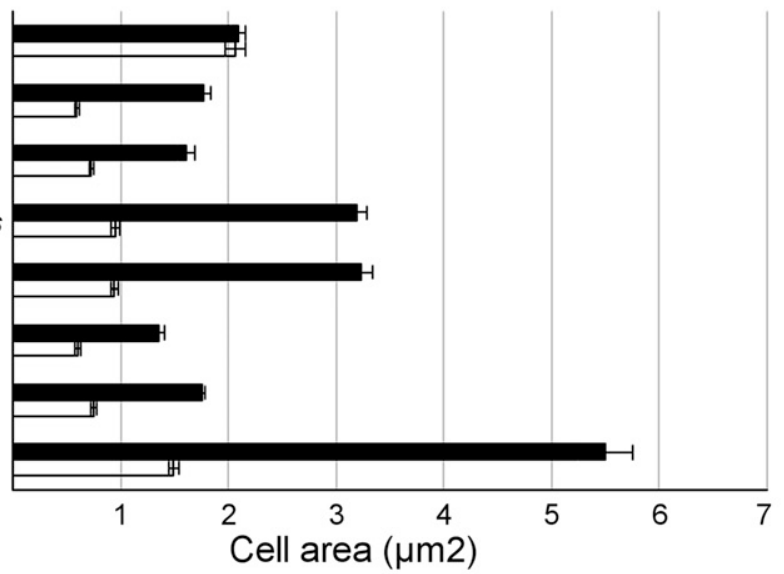

Fig. 3. The size and cell division capacity of the isolated bacteroids. A, The length and $\mathbf{B}$, area of the isolated bacteroids (black bars) were determined from confocal and scanning electron microscopy images $(n>60)$ and were compared with those of free-living bacteria (white bars). C, The relative number of cells that were able to form colonies was determined by plating the bacterial population isolated from the nodules. 
(Bonaldi et al. 2011; Khetmalas and Bal 2005). To quantitatively evaluate the differences between the bacteroids and the free-living rhizobia, the length of the bacteroids and the free-living bacteria was measured from the confocal and SEM images. In all cases, the bacteroids were significantly larger $(P$ value $<0.001$, Student's $t$ test) than the free-living cultured rhizobia (Fig. 3A). Galega orientalis and Ononis spinosa bacteroids showed the greatest difference compared with the free-living bacteria, with an elongation
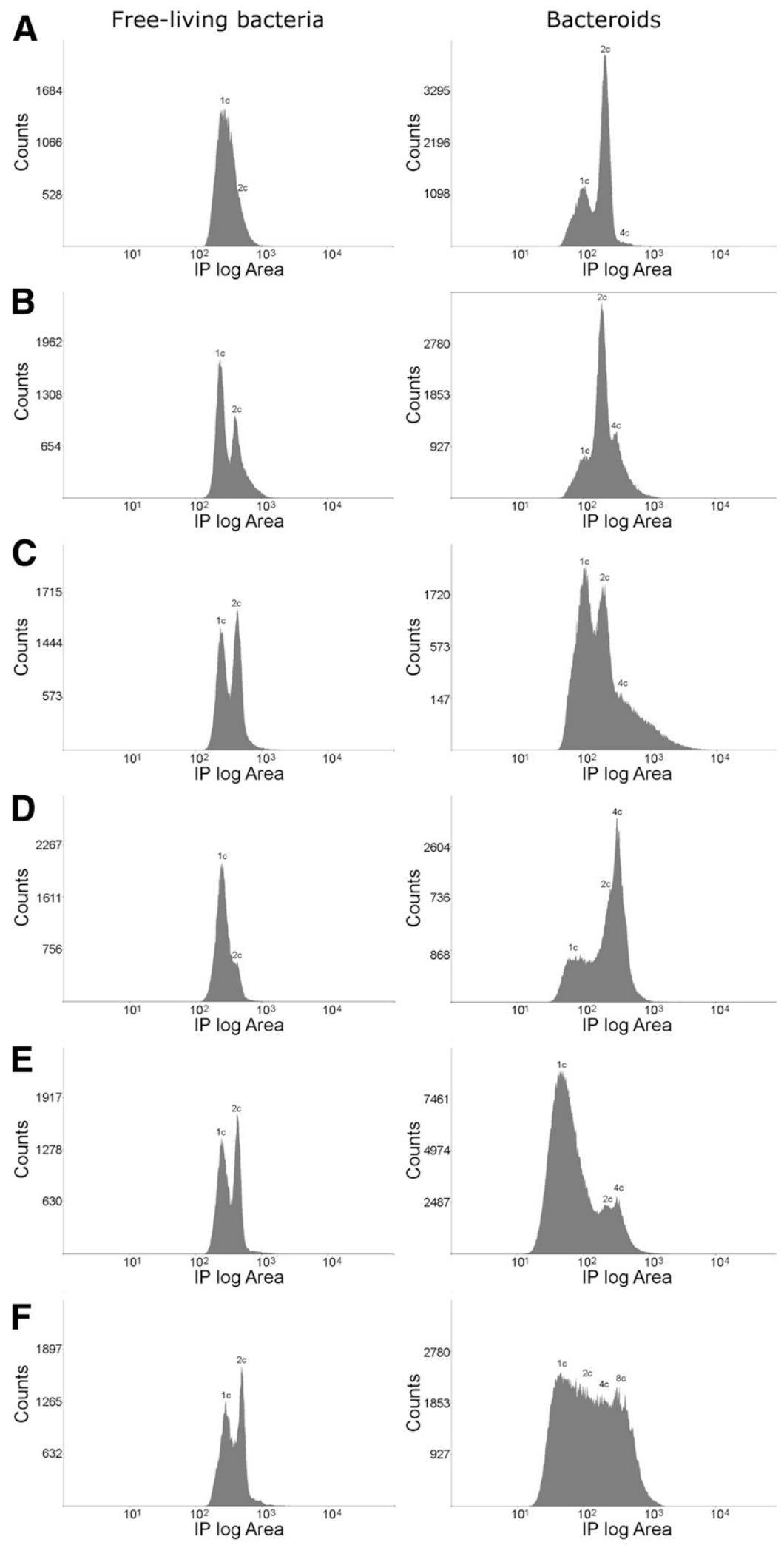

Fig. 4. Genome content of the free-living rhizobia and bacteroids. DNA content of propidium iodide-stained free-living cultured rhizobia used as inoculants and bacteroids isolated from nodules of A, to F, Glycyrrhiza uralensis, B, Onobrychis viciifolia, C, Astragalus canadensis, D, Galega orientalis, E, Cicer arietinum, and F, Ononis spinosa. 
of more than threefold. In Astragalus canadensis and Onobrychis viciifolia, the increase was around 2.5-fold, while in Cicer arietinum and Glycyrrhiza uralensis, it remained below twofold. In addition, the images also revealed an evident increase in the volume of the bacteroids. To evaluate this parameter, the area covered by the bacteroids and that of the corresponding free-living bacteria was quantified. The area of the bacteroids increased at least twofold compared with the free-living cultured rhizobia in Glycirrhiza uralensis, Onobrychis viciifolia, Cicer arietinum, and Ononis spinosa, while in Astragalus canadensis and Galega orientalis, the difference was greater than threefold (Fig. 3B). As controls, U morphotype Bradyrhizobium japonicum USDA110 bacteroids from Glycine max (no size changes) and E morphotype Sinorhizobium medicae WSM419 bacteroids from Medicago truncatula nodules (more than threefold enlargement) were also compared with the corresponding free-living bacteria (Fig. 3B).

Impairment of the reproductive ability of bacteroids.

Terminally differentiated bacteroids are unable to resume growth when released from nodules, while U morphotype bacteroids are able to divide and form colonies (Mergaert et al. 2006). To investigate whether the bacterial population (infecting bacteria and bacteroids) isolated from nodules of the different IRLC legumes are capable of multiplying, the number of colony forming units per milligram of nodule weight was determined at 4 wpi and was compared with the reproduction of the bacterial populations from Glycine max and Medicago truncatula harboring $\mathrm{U}$ and $\mathrm{E}$ morphotype bacteroids, respectively. As expected, the bacterial population from Glycyine max formed the highest number of colonies per milligram of nodule fresh weight while, in the case of all the IRLC legumes tested, the relative number of colonies was 30 - to 400 -fold less (Fig. 3C).
Increment in the DNA content of bacteroids.

Endoreduplication of the infected nodule cells is essential for development of nitrogen-fixing nodules (Vinardell et al. 2003). Gradual increase of cell size by repeated endoreduplication cycles appears to be a general feature of symbiotic nodule cells, which might be required for hosting a large number of rhizobia

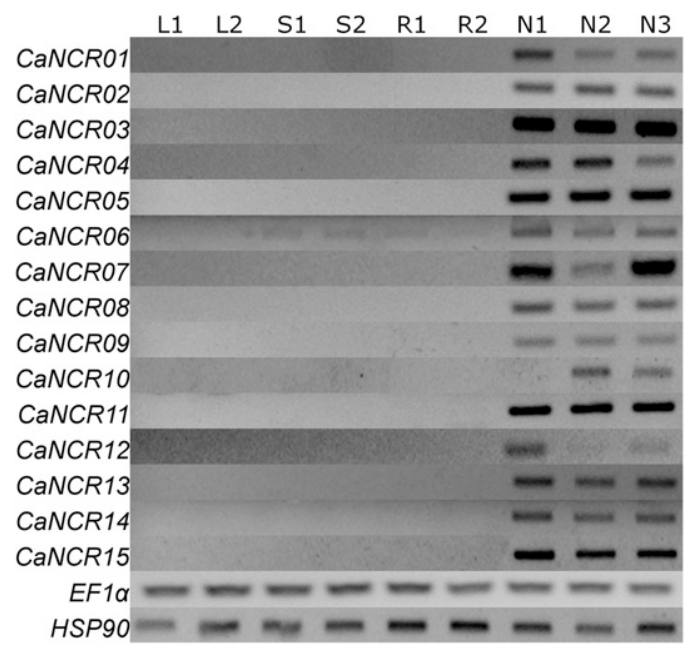

Fig. 5. Expression of nodule-specific cysteine-rich peptide (NCR)-like genes in different organs of Cicer arietinum. Agarose gel electrophoresis profile of reverse transcription-polymerase chain reaction products using specific primers for NCR genes and RNA samples isolated from leaves (L1, L2), shoots (S1, S2), roots (R1, R2), and nodules (N1, N2, N3) of Cicer arietinum. The images show the results of two and three biological replicates. As constitutively active genes, the expression pattern of EF1 $\alpha$ and HSP90 genes were tested.

Table 1. Characteristics of the predicted nodule-specific cysteine-rich peptides in Cicer arietinum $^{\mathrm{a}}$

\begin{tabular}{|c|c|c|c|c|c|c|}
\hline Sequence ID & Amino acid sequence ${ }^{b}$ & $\mathbf{A A}$ & CYS & MW & MW MP & IP MP \\
\hline CaNCR01 & $\begin{array}{l}\text { MAKILKIVYVMILSLLLCFVVTKASTCKDDRDCPNTGNHCIAPDY } \\
\text { MGCMFNNCYCVRRGR }\end{array}$ & 60 & 7 & 6,810 & 3,929 & 7.78 \\
\hline CaNCR02 & $\begin{array}{l}\text { MAQTQKFVYVIILFLSVCLVVTKVASRYCEYDMDCEDYVCTAPEV } \\
\text { SMCIHTYCRCV }\end{array}$ & 56 & 7 & 6,486 & 3,602 & 4.29 \\
\hline CaNCR03 & $\begin{array}{l}\text { MAELLKFVYAIILFLSIFLVVADVGAMCEEDNDCPVFWCFPDQTL } \\
\text { RCITKNCYCLY }\end{array}$ & 56 & 6 & 6,493 & 3,997 & 3.96 \\
\hline CaNCR04 & $\begin{array}{l}\text { MATIHKFVYVMILIVFQLLVVTECLPHRQCTVDSDCPNICHPPKV } \\
\text { PRCFYYQCFCHIIYIVS }\end{array}$ & 62 & 7 & 7,291 & 4,497 & 7.80 \\
\hline CaNCR05 & $\begin{array}{l}\text { MATIHKFVYVMILIIFHFLVLTKGLDDPHCATDDDCKNVCVPPRV } \\
\text { RQCLWSNCYCNVK }\end{array}$ & 58 & 6 & 6,729 & 3,911 & 5.41 \\
\hline CaNCR06 & $\begin{array}{l}\text { MAKTLKVVYTVILLVSLFLLLIAATKQRCKSRVDCKTYPCPIPKV } \\
\text { KSCLNGYCKCVR }\end{array}$ & 57 & 6 & 6,422 & 3,807 & 9.59 \\
\hline CaNCR07 & $\begin{array}{l}\text { MAKTLKVVYTVILLVSLFLLLITAKKMPCKRRRDCKTYPCPHP } \\
\text { KVRDCVKGYCKCVVR }\end{array}$ & 58 & 6 & 6,728 & 4,083 & 9.85 \\
\hline CaNCR08 & $\begin{array}{l}\text { MTKFFMFFFVLWSVFLAFVVSDVSAKVECENDYDCIRLYPQLL } \\
\text { TRCHNGECVVMLYREGVSMKVEN }\end{array}$ & 66 & 4 & 7,800 & 4,852 & 5.09 \\
\hline CaNCR09 & $\begin{array}{l}\text { MVKILKFVYAAILFLVVTHVGCSGESCESASDCPSLWYKCIDHIC } \\
\text { IWLPISTRQK }\end{array}$ & 55 & 5 & 6,204 & 3,613 & 5.49 \\
\hline CaNCR10 & $\begin{array}{l}\text { MVGIVKFVRVMVFFFFLFNIGMNLVDMCKHPGSIPQCHWGWC } \\
\text { ICVIMMGPLPHPTIHNQLQ }\end{array}$ & 61 & 4 & 7,061 & 4,322 & 7.06 \\
\hline CaNCR11 & $\begin{array}{l}\text { MVGIVKFVCVMVFFFFLFNIGMNLVEAHPRYPCTKDEDCPKDM } \\
\text { CKYPGSYPRCVWGWCECFVKMRPLRRPIKRKQLQ }\end{array}$ & 77 & 7 & 9,229 & 6,131 & 9.38 \\
\hline CaNCR12 & $\begin{array}{l}\text { MAQIFVFVYALIIFLSLSLVVSMEKKAPCNSWRDCEEFDYYEVAC } \\
\text { IDGFCEYQYTCE }\end{array}$ & 57 & 5 & 6,726 & 4,270 & 4.06 \\
\hline CaNCR13 & $\begin{array}{l}\text { MAKTLKVVYTVILLVSLFLLLIAATKPCQSDKDCKKFACRKPK } \\
\text { VPKCINGFCKCVR }\end{array}$ & 56 & 6 & 6,276 & 3,660 & 9.59 \\
\hline CaNCR14 & $\begin{array}{l}\text { MAKTLKVVYTVILLVSLFLLLIAASRDCKTYPCPPSKVKDCIKGY } \\
\text { CKCVR }\end{array}$ & 50 & 5 & 5,594 & 2,979 & 9.20 \\
\hline CaNCR15 & $\begin{array}{l}\text { MAKTLKVVYIVILLVSLFLLLIAATKQPCKSRKHCKTYRCPTPKV } \\
\text { PNCVNGFCKCVR }\end{array}$ & 57 & 6 & 6,439 & 3,812 & 9.82 \\
\hline
\end{tabular}

\footnotetext{
a The number of amino acids (AA) and cysteines (CYS) as well as the molecular weight (MW) of the predicted gene products are shown. The molecular weight and the isoelectric point of the mature peptides (MW MP and IP MP, respectively) were calculated with an ExPASy online tool.

$\mathrm{b}$ The predicted mature peptides are shown in bold.
} 
and for altered physiology of the cells (Cebolla et al. 1999; Kondorosi et al. 2013). Using a flow cytometer, we measured the DNA content of 4',6-diamidino-2-phenylindole (DAPI)stained nuclei from the nodules of the tested legumes. This analysis revealed the presence of cells with polyploid DNA content (Supplementary Fig. S2). Astragalus canadensis and Cicer arietinum nodules had cells with ploidy levels up to $128 \mathrm{C}$; in Galega orientalis, Glycyrrhiza uralensis, and Onobrychis viciifolia, nuclei with DNA content of 64C were found; while in Ononis spinosa, cells with 32C DNA content could be found. With the exception of Onobrychis viciifolia, the peak with the highest number of counts was at $4 \mathrm{C}$.

Similarly, the DNA content of the bacteroids was also measured and compared with cultured bacteria in order to find out whether the increased size of bacteroids is associated with genome amplification (Fig. 4). The free-living bacteria had 1C or $2 \mathrm{C}$ DNA content, while the endosymbiont population containing bacteroids at different stages of their differentiation and fully functioning nitrogen-fixing bacteroids contained higher DNA content, with peaks at 4C and up to 8C in Ononis spinosa.

These data together with the altered morphology of bacteroids, reduced reproductive capacity, and increased DNA content indicate that the bacteroids in these IRLC legumes also undergo terminal differentiation.

\section{IRLC nodules express $N C R$ genes.}

As NCR peptides are plant factors of terminal bacteroid differentiation, we investigated whether NCR or NCR-like genes are present and expressed in these legume nodules. We searched the publicly available sequence databases for such entries. Homologous expressed genes have been found in other legumes from the IRLC, including two genera (Galega and Astragalus) also used in our study and other species such as Vicia faba, Medicago sativa, Trifolium repens, and Pisum sativum in agreement with previous reports (Chou et al. 2006; Crockard et al. 2002; Frühling et al. 2000; Jiménez-Zurdo et al. 2000; Kaijalainen et al. 2002; Kato et al. 2002; Mergaert et al. 2003). Unfortunately, no genomic and nodule transcriptome sequence data were available from Glycyrrhiza, Onobrychis, and Ononis species, while in the genome and nodule transcriptome sequences of Cicer arietinum (Afonso-Grunz et al. 2014; Molina et al. 2011; Varshney et al. 2013), no gene coding for an NCR peptide has been annotated. Using an in silico analysis, however, we could identify 15 putative genes with coding capacity for NCR-like peptides in the genome of Cicer arietinum (Table 1) (GenBank accession numbers are shown in Supplementary Table S1). The predicted proteins contained putative secretory signal sequences, four to seven cysteine residues at the conserved positions, and had a molecular mass ranging from 7 to $11 \mathrm{kDa}$. To determine whether these predicted NCR-like genes are transcribed, reverse transcription-polymerase chain reaction (PCR) experiments were carried out using RNA isolated from leaves, shoots, uninoculated roots, and nodules collected at 4 wpi. The transcript of all the 15 predicted genes could be detected specifically in the nodules (Fig. 5). A very low expression of the CaNCRO6 gene could also be observed in shoots and roots. These expression data are in agreement with the transcriptome data obtained on the NCR genes of Medicago truncatula (Guefrachi et al. 2014) and suggest that NCR peptides might play a role in bacteroid development in these species, too.

\section{DISCUSSION}

A study on the evolution of the macrosymbiont's effects on bacteroid morphology in the Papilionoideae subfamily of legumes revealed five likely independent origins for host- imposed bacteroid swelling, i.e., for plant-directed terminal bacteroid differentiation (Oono et al. 2010). The existence of two different swelled forms, namely the elongated or branched E morphotype and the spherical S morphotype, suggested two different strategies and two different underlying mechanisms for swelling. In IRLC, one of the five lineages with swollen bacteroids, the appearance of this trait was placed in the Vicioid subclade (Fig. 1) after the Cicereae tribe separated from the common ancestor of those tribes that contain Trifolium, Lathyrus, Pisum, Vicia, Medicago, Melilotus, and Trigonella species (Oono et al. 2010; Wojciechowski et al. 2004). Previous studies, however, reported enlarged bacteroids in the most basal Vicioid legume, Galega orientalis (Lipsanen and Lindström 1988) as well as in an Astragalus species (Wdowiak et al. 2000) of the Astragalean clade (Fig. 1), indicating that this trait might be more widespread in the IRLC than thought. In this study, we provide evidence that, indeed, in all branches of the IRLC from the most basal Glycyrrhiza species through the Hedysaroid and Astragalean subclades to the Vicioid legumes, the bacteroids are terminally differentiated. This statement is supported by observations that, in all studied species, the bacteroids are larger as well as have higher DNA content than the free-living cells and the reproductive capacity of the bacterial population (infecting bacteria and bacteroids) in the nodules is much lower than that of the $\mathrm{U}$ morphotype Bradyrhizobium japonicum population in soybean. In addition, not only elongated but $\mathrm{S}$ morphotype-like spherical bacteroids could be observed in certain species as well, indicating a more complex evolution of bacteroid differentiation than anticipated. In all IRLC legumes with available sequence resources, nodule-specific expression of NCR-like genes can be detected again, indicating that the hosts might direct the differentiation of the bacteroids via the action of the peptides.

\section{Size, morphotype, and reproductive capacity of bacteroids.}

Terminal bacteroid differentiation in the most intensively studied IRLC legumes (Medicago, Pisum, Vicia species) is accompanied by extreme changes in the morphology and the size of bacteria, and the latter became the decision factor for Oono et al. (2010) in the absence of data on DNA content, when the morphotype of bacteroids was categorized. The comparison of free-living bacteria and bacteroids in this study revealed that the size of cultured cells is not the same for all species and bacteroids in the nodules of the IRLC legumes are almost two times or more larger than the free-living bacteria, in contrast to the Bradyrhizobium-soybean symbiosis in which the two forms of the microsymbiont have the same size. Another feature of terminal bacteroid differentiation in Medicago species is the uniform amplification of all three or more replicons of the bacterial genome via endoreduplication and its organization in multiple nucleoids (Mergaert et al. 2006). Likewise an increase in the DNA content of the bacteroids was found in all IRLC legumes investigated in this and earlier studies (Mergaert et al. 2006). The proper distribution of all replicons of the genome into the daughter cells during cell division may be disturbed if multiple copies of the DNA molecules are present in the dividing cell, which can result in the loss or reduction of cell division capacity, i.e., of the ability to form colonies (Kondorosi et al. 2013). Here, we show that the bacterial populations (infecting bacteria and bacteroids) isolated from the IRLC nodules had much lower colony forming capacity than the U morphotype Bradyrhizobium japonicum population in soybean; thus, the third characteristic of terminal bacteroid differentiation was observed in all tested IRLC legumes. Therefore, it was concluded that all branches of the IRLC legumes impose terminal bacteroid differentiation on the symbiotic partner, 
although the degree of bacterial cell enlargement can vary. In the light of these observations, it might be interesting to reanalyze the data used for the investigation of this trait's evolution by determining either the cell division capacity, the DNA content of the bacterial populations, or both. For example, bacteroids in the Mirbelioid species Aotus ericoides, which averaged about double the size of free-living bacteria (Oono et al. 2010), as well as other small and medium sized bacteroids in the different species might also be terminally differentiated, similarly to the microsymbionts of Gompholobius species in the same clade.

Morphological changes such as branching of the cells are also observed in terminally differentiated bacteroids; however, branching seems more predominant in Pisum and Vicia species than in Medicago species (Mergaert et al. 2006). Similarly to Medicago species, a low incidence of cell branching was found in Galega orientalis, while no such change could be detected in the other investigated IRLC legumes. Interestingly, spherical, ball-like bacteroids are formed in the nodules of Ononis spinosa that are reminiscent of the $\mathrm{S}$ morphotype cells observed only in nodules of the Dalbergoid species Arachys and Aeschynomene (Bonaldi et al. 2011; Khetmalas and Bal 2005). The presence of both $\mathrm{E}$ and $\mathrm{S}$ morphotype bacteroids in closely related species is not unprecedented, because members of the Aeschynomene genus host either $\mathrm{E}$ or $\mathrm{S}$ morphotype bacteroids, depending on the species (Bonaldi et al. 2011). These observations might indicate that, after all, there might be only one origin of swelling; however, there might be two underlying mechanisms leading to the formation of the $\mathrm{E}$ and $\mathrm{S}$ morphotype bacteroids. This idea is strengthened by the observation that disturbing the targeting of NCR-like peptides to the developing bacteroids in Aeschynomene evenia subsp. serrulata via the partial (65\%) silencing of the DNF1 gene coding for an element of signal peptidease complex resulted in various bacteroid morphotypes within the same cell or in elongated bacteroids instead of spherical ones (Czernic et al. 2015). Comparison of $\mathrm{E}$ and $\mathrm{S}$ morphotype bacteroid differentiation within lineages as well as $\mathrm{S}$ versus $\mathrm{S}$ and $\mathrm{E}$ versus $\mathrm{E}$ morphotype development across taxonomic groups might help to reveal the underlying mechanisms. The formation of both morphotypes requires the amplification of the genome, but the genes and proteins and the mechanisms behind the morphological changes are unknown; thus, it is impossible to predict at present whether bacteria infecting the plants belonging to the two clades respond to the plant factors directing their differentiation with the same mechanism. Similarly, it is unknown whether genus Ononis targets the bacteria with NCR-like peptides and whether the spherical bacteroids are formed the same way as the elongated cells in the other IRLC plants.

\section{NCRs and bacteroid differentiation.}

Terminal bacteroid differentiation in IRLC legumes was hypothesized to be directed by factors that are not present in plants (such as Lotus and Glycine species). In Medicago truncatula, NCR peptides encoded by a large gene family containing approximately 600 genes that are scattered on all eight chromosomes have been supposed to be these factors (Mergaert et al. 2003; Maroti and Kondorosi 2014). Later, it was demonstrated in vitro that NCR peptides can cause changes such as membrane permeabilization, genome endoreduplication, and cell enlargement that are associated with the terminal differentiation of bacteroids and that their targeting to the symbiotic compartment is essential for symbiotic development (Van de Velde et al. 2010). It was also shown that a peptide (NCR247) can contribute to bacteroid differentiation through multiple mechanisms, for example, by affecting cell division, translation, or the activity of the GroEL chaperone (Farkas et al. 2014). Very recently, it was also revealed that lack of even a single NCR peptide can prevent the completion of the differentiation process, resulting in ineffective interaction (Horváth et al. 2015). Interestingly, the Dalbergoid legume species of the Aeschynomene genus housing $\mathrm{S}$ or $\mathrm{E}$ morphotype bacteroids produce NCR peptides that have no sequence homology to the NCR peptides of IRLC legumes, indicating an independent evolutionary origin (Czernic et al. 2015). There seem to be a correlation between the expression of NCR-like genes and terminal bacteroid differentiation; thus, in all IRLC legumes studied, the expression of NCR-like sequences has been expected. Earlier, suppressive subtractive hybridization was applied in Astragalus (Chou et al. 2006) and Galega species (Kaijalainen et al. 2002) to identify nodule-specific transcripts, and some of those nodulin genes have coding capacity for NCR peptides. Although no NCR gene has been annotated in the genome and nodule transcriptome of Cicer arietinum, 15 sequences could be shown to code for NCR-like peptides and to be expressed exclusively (14 genes) or at an enhanced level ( 1 gene) in nodules. The number of the NCR peptides in Cicer species is much lower than in Medicago species; however, to tell whether there is a correlation between the degree of cell enlargement and the multitude of the peptides, the discovery and counting of expressed $N C R$ sequences from a number of IRLC lineages is needed. In addition, this investigation might reveal the evolution of the gene family and might identify the ancestral genes as well as conserved members that had maintained their function in the course of evolution.

\section{MATERIALS AND METHODS}

Seed germination, growth conditions, and inoculation.

Seeds from Astragalus canadensis, Galega orientalis, Glycyrrhiza. uralensis, and Ononis spinosa were scarified by sulfuric acid treatment $(10 \mathrm{~min})$. After scarification, the seeds were washed four times with sterile distillated water. Cicer arietinum, Onobrychis viciifolia, and Glycine max seeds did not need chemical or physical scarification. Later, the seeds were surface sterilized with $0.1 \%$ (wt/vol) $\mathrm{HgCl}_{2}$ for $3 \mathrm{~min}$ and were washed with sterile distillated water to remove the $\mathrm{HgCl}_{2}$. Surface-sterilized seeds were germinated at room temperature for 48 to $72 \mathrm{~h}$ and the seedlings were planted in pods containing zeolite. The next day, the seedlings were inoculated with their respective rhizobial species obtained from the University of Helsinki, Faculty of Agriculture and Forestry, Division of Microbiology and Biotechnology (HAMBI) culture collection as follows: Astragalus canadensis with Mesorhizobium sangaii (HAMBI 3318), Cicer arietinum with Mesorhizobium ciceri (HAMBI2949), Galega orientalis with Rhizobium galegae bv. orientalis (HAMBI 0540), Glycyrrhiza uralensis with Mesorhizobium tianshanense (HAMBI 3372), Onobrychis viciifolia with Rhizobium sp. (HAMBI 2045), and Ononis spinosa with Rhizobium sp. (HAMBI 2029). Nodules were harvested to perform further experiments at $4 \mathrm{wpi}$, when nodules were fully developed and pink.

\section{Flow cytometry analysis.}

Nodules were chopped up in Galbraith solution with razor blades to release the bacteroids and nuclei, and then, the homogenate was passed through a $20-\mu \mathrm{m}$ filter to discard plant debris. The filtered homogenate was stained with propidium iodide (PI) $(50 \mu \mathrm{g} / \mathrm{ml})$ to analyze the DNA content of the bacteroids or with DAPI $(0.5 \mu \mathrm{g} / \mathrm{ml})$ to evaluate the ploidy level of the nuclei in a Moflo Astrio cytometer from Beckman Coulter driven by Summit 6.1 software. 


\section{Confocal microscopy.}

Nodules were embedded in Technovit resin for their histological analysis, following the manufacturer's instructions (Technovit 7100). Thin sections of nodules $(7 \mu \mathrm{m})$ were prepared using a microtome and were stained with PI $(50 \mu \mathrm{g} / \mathrm{ml})$. Bacteroids isolated from nodules and free-living, cultured rhizobia were heat-treated $\left(70^{\circ} \mathrm{C}\right.$ for $\left.10 \mathrm{~min}\right)$ and were stained with PI. Fluorescent images were acquired with an Olympus Fluoview FV1000 confocal laser scanning microscope.

\section{SEM.}

Nodules were embedded into $10 \%$ low-melting agarose and $150-\mu \mathrm{m}$-thick sections were prepared using a Leica VT1200S vibrotome. Sections were fixed in $2.5 \%$ glutaraldehyde in $0.05 \mathrm{M}$ cacodylate buffer ( $\mathrm{pH} 7.5$ ) for $2 \mathrm{~h}$ at room temperature, and then, the samples were dehydrated through a series of ethanol baths (from 50 to $100 \%$ ). Next, the samples were washed in mixtures of ethanol and t-butyl alcohol with different ratios $(2: 1,1: 1,1: 2)$ followed by a final absolute t-butyl alcohol bath. Samples were freeze-dried for 2 to $4 \mathrm{~h}$ and were fixed on a SEM stage prior to coating with platinum at approximately $0.9 \mathrm{~nm}$ thickness. Samples were examined under an accelerating voltage of $15 \mathrm{kV}$ with a working distance of $16 \mathrm{~mm}$, using an FEI Quanta scanning electron microscope.

\section{Colony-forming ability.}

Fresh nodules were collected at 4 wpi, their weight was measured, and they were surface-sterilized with $70 \%$ ethanol for $10 \mathrm{~min}$. After several washes with sterile distillated water, the nodules were crushed with a micropestle and serial dilutions of the homogenate were plated into appropriate media. Plates were incubated at $30^{\circ} \mathrm{C}$ for 2 to 5 days and the number of colonies was counted. Data from three biological replicates with two to three technical repeats were collected using at least $10 \mathrm{mg}$ of nodules per biological replicate.

\section{Expression analysis of the $\mathrm{NCR}$-like genes.}

Total RNA was isolated from the tissues of Cicer arietinum with the help of Trizol (Life Technologies), according to the manufacturer's instructions, and was quantified with a NanoDrop spectrophotometer. The integrity of the RNA was evaluated by agarose gel electrophoresis. DNA was eliminated by DNAse treatment and cDNA synthesis was carried out using the high capacity cDNA reverse transcription kit from Life Technologies. cDNA (100 ng) was used as template for semiquantitative PCR assays using the Kapa Taq PCR kit with the following conditions: 1 cycle $95^{\circ} \mathrm{C}$ for $2 \mathrm{~min}, 35$ cycles of $30 \mathrm{~s}$ denaturation $\left(95^{\circ} \mathrm{C}\right)$, $30 \mathrm{~s}$ annealing $\left(55\right.$ and $\left.60^{\circ} \mathrm{C}\right)$, and 20 s elongation $\left(72^{\circ} \mathrm{C}\right)$. EFl $\alpha$ and HSP9O genes were used as reference genes (Garg et al. 2010). For each oligonucleotide pair, the presence of a unique product was assessed by analysis of the melting curve.

\section{ACKNOWLEDGMENTS}

We thank M. Bourge and R. M. Lima for technical assistance with the flow cytometry and confocal microscopy analysis, respectively. This work has benefited from the facilities and expertise of the Imagif Cell Biology Unit of the Centre National de la Recherche Scientifique campus in Gif-sur-Yvette, France. Work in our laboratories is supported by the "SYM-BIOTICS" Advanced Grant of the European Research Council to É. Kondorosi (grant number 269067) and by the OTKA grant NN110979 from the Hungarian National Research Fund to A. Kereszt. J. Montiel is supported by a postdoctoral fellowship from the Consejo Nacional de Ciencia y Tecnología in Mexico (proposal 231205).

\section{LITERATURE CITED}

Afonso-Grunz, F., Molina, C., Hoffmeier, K., Rycak, L., Kudapa, H., Varshney, R. K., Drevon, J. J., Winter, P., and Kahl, G. 2014. Genome- based analysis of the transcriptome from mature chickpea root nodules Front. Plant Sci. 5:325.

Alunni, B., Kevei, Z., Redondo-Nieto, M., Kondorosi, A., Mergaert, P., and Kondorosi, E. 2007. Genomic organization and evolutionary insights on GRP and NCR genes, two large nodule-specific gene families in Medicago truncatula. Mol. Plant-Microbe Interact 20:1138-1148.

Bergersen, F. J. 1955. The cytology of bacteroids from root nodules of subterranean clover (Trifolium subterraneum L.). J. Gen. Microbiol. 13: 411-419.

Bonaldi, K., Gargani, D., Prin, Y., Fardoux, J., Gully, D., Nouwen, N., Goormachtig, S., and Giraud, E. 2011. Nodulation of Aeschynomene afraspera and $A$. indica by photosynthetic Bradyrhizobium sp. strain ORS285: The nod-dependent versus the nod-independent symbiotic interaction. Mol. Plant-Microbe Interact 24:1359-1371.

Cebolla, A., Vinardell, J.M., Kiss, E., Oláh, B., Roudier, F., Kondorosi, A., and Kondorosi, E. 1999. The mitotic inhibitor ccs52 is required for endoreduplication and ploidy-dependent cell enlargement in plants. EMBO (Eur. Mol. Biol. Organ) J. 18:4476-4484.

Chou, M. X., Wei, X. Y., Chen, D. S., and Zhou, J. C. 2006. Thirteen nodule-specific or nodule-enhanced genes encoding products homologous to cysteine cluster proteins or plant lipid transfer proteins are identified in Astragalus sinicus L. by suppressive subtractive hybridization. J. Exp. Bot. 57:2673-2685.

Crockard, M., Bjourson, J., Dazzo, B., and Cooper, J. E. 2002. A white clover nodulin gene, $d d 23 b$, encoding a cysteine cluster protein, is expressed in roots during the very early stages of interaction with Rhizobium leguminosarum biovar trifolii and after treatment with chitolipooligosaccharide Nod factors. J. Plant Res. 115:439-447.

Czernic, P., Gully, D., Cartieaux, F., Moulin, L., Guefrachi, I., Patrel, D., Pierre, O., Fardoux, J., Chaintreuil, C., Ngyugen, P., Gressent, F., Da Silva, C., Poulain, J., Wincker, P., Rofidal, V., Hem, S., Barriere, Q., Arrighi, J. F., Mergaert, P., and Giraud, E. 2015. Convergent evolution of endosymbiont differentiation in dalbergioid and IRLC legumes mediated by nodule-specific cysteine rich peptides. Plant Physiol. 169: 1254-1265.

Farkas, A., Maroti, G., Dürgo, H., Györgypál, Z., Lima, R. M., Medzihradzky, F., Kereszt, A., Mergaert, P., and Kondorosi, E. 2014 Medicago truncatula symbiotic peptide NCR247 contributes to bacteroid differentiation through multiple mechanisms. Proc. Natl. Acad. Sci. U.S.A. 111:5183-5188.

Ferguson, B. J., Indrasumunar, A., Hayashi, S., Lin, M. H., Lin, Y. H., Reid, D. E., and Gresshoff, P. M. 2010. Molecular analysis of legume nodule development and autoregulation. J. Integr. Plant Biol. 52:6176.

Frühling, M., Algus, U., Hohnjec, N., Geise, G., Pühler, A., and Perlick, A. M. 2000. A small gene family of broad bean codes for late nodulins containing conserved cysteine clusters. Plant Sci. 152:67-77.

Garg, R., Sahoo, A., Tyagi, A. K., and Jain, M. 2010. Validation of internal control genes for quantitative gene expression studies in chickpea (Cicer arietinum L.). Biochem. Biophys. Res. Commun. 396:283-288.

Guefrachi, I., Nagymihaly, M., Pislariu, C.I., Van de Velde, W., Ratet, P., Mars, M., Udvardi, M.K., Kondorosi, E., Mergaert, P., and Alunni, B. 2014. Extreme specificity of NCR gene expression in Medicago truncatula. BMC Genomics 15:712. doi:10.1186/1471-2164-15-712

Graham, P. H., and Vance, C. P. 2003. Legumes: Importance and constraints to greater use. Plant Physiol. 131:872-877.

Horváth, B., Domonkos, A., Kereszt, A., Szűcs, A., Ábrahám, E., Ayaydin, F., Bóka, K., Chen, Y., Chen, R., Murray, J. D., Udvardi, M. K., Kondorosi, E., and Kaló, P. 2015. Loss of the nodule-specific cysteine rich peptide, NCR169, abolishes symbiotic nitrogen fixation in the Medicago truncatula dnf7 mutant. Proc. Natl. Acad. Sci. U.S.A. 112:1523215237.

Jiménez-Zurdo, J. I., Frugier, F., Crespi, M. D., and Kondorosi, A. 2000. Expression profiles of 22 novel molecular markers for organogenetic pathways acting in alfalfa nodule development. Mol. Plant-Microbe Interact 13:96-106.

Kaijalainen, S., Schroda, M., and Lindstrom, K. 2002. Cloning of nodulespecific cDNAs of Galega orientalis. Physiol. Plant. 114:588-593.

Kato, T., Kawashima, K., Miwa, M., Mimura, Y., Tamaoki, M., Kouchi, H., and Suganuma, N. 2002. Expression of genes encoding late nodulins characterized by a putative signal peptide and conserved cysteine residues is reduced in ineffective pea nodules. Mol. Plant-Microbe Interact 15:129-137.

Khetmalas, M. B., and Bal, A. K. 2005. Microscopical studies of Arachis pintoi root nodule with special reference to bacteroids and oleosomes at different stages of plant growth and nodule development. Plant Sci. 168: 557-563. 
Kondorosi, E., Mergaert, P., and Kereszt, A. 2013. A paradigm for endosymbiotic life: Cell differentiation of Rhizobium bacteria provoked by host plant factors. Annu. Rev. Microbiol. 67:611-628.

Lee, H., and Copeland, L. 1994. Ultrastructure of chickpea nodules. Protoplasma 182:32-38.

Lipsanen, P., and Lindström, K. 1988. Infection and root nodule structure in the Rhizobium galegae sp. nov.-Galega sp. simbiosis. Symbiosis 6:8189.

Maroti, G., and Kondorosi, E. 2014. Nitrogen-fixing Rhizobium-legume symbiosis: Are polyploidy and host peptide-governed symbiont differentiation general principles of endosymbiosis? Front. Microbiol. 5:326.

Mergaert, P., Nikovics, K., Kelemen, Z., Maunoury, N., Vaubert, D., Kondorosi, A., and Kondorosi, E. 2003. A novel family in Medicago truncatula consisting of more than 300 nodule-specific genes coding for small, secreted polypeptides with conserved cysteine motifs. Plant Physiol. 132:161-173.

Mergaert, P., Uchiumi, T., Alunni, B., Evanno, G., Cheron, A., Catrice, O., Mausset, A. E., Barloy-Hubler, F., Galibert, F., Kondorosi, A., and Kondorosi, E. 2006. Eukaryotic control on bacterial cell cycle and differentiation in the Rhizobium-legume symbiosis. Proc. Natl. Acad. Sci. U.S.A. 103:5230-5235.

Molina, C., Zaman-Allah, M., Khan, F., Fatnassi, N., Horres, R., Rotter, B., Steinhauer, D., Amenc, L., Drevon, J. J., Winter, P., and Kahl, G. 2011. The salt-responsive transcriptome of chickpea roots and nodules via deepSuperSAGE. BMC Plant Biol. 11:31.

Oono, R., and Denison, R. F. 2010. Comparing symbiotic efficiency between swollen versus nonswollen rhizobial bacteroids. Plant Physiol. 154:1541-1548.

Oono, R., Schmitt, I., Sprent, J. I., and Denison, R. F. 2010. Multiple evolutionary origins of legume traits leading to extreme rhizobial differentiation. New Phytol. 187:508-520.

Popp, C., and Ott, T. 2011. Regulation of signal transduction and bacterial infection during root nodule symbiosis. Curr. Opin. Plant Biol. 14:458-467.

Sen, D., and Weaver, R. W. 1981. A comparison of nitrogen-fixing ability of peanut, cowpea and siratro plants nodulated by different strains of Rhizobium. Plant Soil 60:317-319.

Van de Velde, W., Zehirov, G., Szatmari, A., Debreczeny, M., Ishihara, H., Kevei, Z., Farkas, A., Mikulass, K., Nagy, A., Tiricz, H., Satiat-Jeunemaitre, B., Alunni, B., Bourge, M., Kucho, K., Abe, M., Kereszt, A., Maroti, G., Uchiumi, T., Kondorosi, E., and Mergaert, P. 2010. Plant peptides govern terminal differentiation of bacteria in symbiosis. Science 327:1122-1126.

Vance, C. P., Graham, P. H., and Allan, D. L. 2000. Biological nitrogen fixation. Phosphorus: A critical future need. Pages 506-514 in: Nitrogen Fixation: From Molecules to Crop Productivity. F. O. Pedrosa, M. Hungria, M. G. Yates, and W. E. Newton, eds. Kluwer Academic Publisher, Dordrecht, The Netherlands.

Varshney, R. K., Song, C., Saxena, R. K., Azam, S., Yu, S., Sharpe, A. G., Cannon, S., Baek, J., Rosen, B. D., Tar'an, B., Millan, T., Zhang, X., Ramsay, L. D., Iwata, A., Wang, Y., Nelson, W., Farmer, A. D., Gaur, P. M., Soderlund, C., Penmetsa, R. V., Xu, C., Bharti, A. K., He, W., Winter, P., Zhao, S., Hane, J. K., Carrasquilla-Garcia, N., Condie, J. A., Upadhyaya, H. D., Luo, M. C., Thudi, M., Gowda, C. L., Singh, N. P.,
Lichtenzveig, J., Gali, K. K., Rubio, J., Nadarajan, N., Dolezel, J., Bansal, K. C., Xu, X., Edwards, D., Zhang, G., Kahl, G., Gil, J., Singh, K. B., Datta, S. K., Jackson, S. A., Wang, J., and Cook, D. R. 2013. Draft genome sequence of chickpea (Cicer arietinum) provides a resource for trait improvement. Nat. Biotechnol. 31:240-246.

Vasse, J., de Billy, F., Camut, S., and Truchet, G. 1990. Correlation between ultrastructural differentiation of bacteroids and nitrogen fixation in alfalfa nodules. J. Bacteriol. 172:4295-4306.

Vinardell, J. M., Fedorova, E., Cebolla, A., Kevei, Z., Horvath, G., Kelemen, Z., Tarayre, F., Mergaert, P., Kondorosi, A., and Kondorosi, E. 2003. Endoreduplication mediated by the anaphase-promoting complex activator CCS52A is required for symbiotic cell differentiation in Medicago truncatula nodules. Plant Cell 15:2093-2105.

Wdowiak, S., Malek, W., Sajnaga, E., Lotocka, B., Stepkowski, T., and Legocki, A. 2000. Symbiosis of Astragalus cicer with its microsymbionts: Partial nodC gene sequence, host plant specificity, and root nodule structure. Antonie van Leeuwenhoek 78:63-71.

Wojciechowski, M. F., Lavin, M., and Sanderson, M. J. 2004. A phylogeny of legumes (Leguminosae) based on analysis of the plastid matK gene resolves many well-supported subclades within the family. Am. J. Bot. 91:1846-1862.

Young, N. D., Debelle, F., Oldroyd, G. E., Geurts, R., Cannon, S. B., Udvardi, M. K., Benedito, V. A., Mayer, K. F., Gouzy, J., Schoof, H., Van de Peer, Y., Proost, S., Cook, D. R., Meyers, B. C., Spannagl, M., Cheung, F., De Mita, S., Krishnakumar, V., Gundlach, H., Zhou, S., Mudge, J., Bharti, A. K., Murray, J. D., Naoumkina, M. A., Rosen, B., Silverstein, K. A., Tang, H., Rombauts, S., Zhao, P. X., Zhou, P., Barbe, V., Bardou, P., Bechner, M., Bellec, A., Berger, A., Berges, H., Bidwell, S., Bisseling, T., Choisne, N., Couloux, A., Denny, R., Deshpande, S., Dai, X., Doyle, J. J., Dudez, A. M., Farmer, A. D., Fouteau, S., Franken, C., Gibelin, C., Gish, J., Goldstein, S., Gonzalez, A. J., Green, P. J., Hallab, A., Hartog, M., Hua, A., Humphray, S. J., Jeong, D. H., Jing, Y., Jocker, A., Kenton, S. M., Kim, D. J., Klee, K., Lai, H., Lang, C., Lin, S., Macmil, S. L., Magdelenat, G., Matthews, L., McCorrison, J., Monaghan, E. L., Mun, J. H., Najar, F. Z., Nicholson, C., Noirot, C., O’Bleness, M., Paule, C. R., Poulain, J., Prion, F., Qin, B., Qu, C., Retzel, E. F., Riddle, C., Sallet, E., Samain, S., Samson, N., Sanders, I., Saurat, O., Scarpelli, C., Schiex, T., Segurens, B., Severin, A. J., Sherrier, D. J., Shi, R., Sims, S., Singer, S. R., Sinharoy, S., Sterck, L., Viollet, A., Wang, B. B., Wang, K., Wang, M., Wang, X., Warfsmann, J., Weissenbach, J., White, D. D., White, J. D., Wiley, G. B., Wincker, P., Xing, Y., Yang, L., Yao, Z., Ying, F., Zhai, J., Zhou, L., Zuber, A., Denarie, J., Dixon, R. A., May, G. D., Schwartz, D. C., Rogers, J., Quetier, F., Town, C. D., and Roe, B. A. 2011. The Medicago genome provides insight into the evolution of rhizobial symbioses. Nature 480:520-524.

\section{AUTHOR-RECOMMENDED INTERNET RESOURCES}

ExPASy Compute pI/Mw tool: http://web.expasy.org/compute_pi HAMBI culture collection: http://www.helsinki.fi/hambi 